\title{
THE ONTOLOGICAL CONTEXT OF GADAMER'S "FUSION": BOEHME, HEIDEGGER, AND NON-DUALITY
}

\author{
ROBERT H. PASLICK \\ University of Michigan
}

The notion that there can be no ultimately objective point of view by which the truth of a thing can be determined with absolute certainty is not congenial to the Western mind. It threatens to undermine the principle values of prediction and control on which the advance of technology continues to rest. Precisely what characterizes contemporary critical theory, however, particularly if schooled by Nietzsche's philosophical hammer, is the realization that theory, especially of a dogmatic kind, can easily become the child of ideology. We are witnessing an ever increasing concern about establishing a more explicit philosophical foundation for critical activity and are consequently becoming unusually open to the influences of European thought, particularly from hermeneutic and deconstructionist camps. We are gradually waking up to the unconscious presuppositions of our critical commonplaces and are discovering, as the Europeans have been discovering since the dissemination of Nietzsche's major writings, that we are caught on the dual horns of the Cartesian and Neo-Kantian dilemma. Typical of the new sound on the American critical scene is the following attack by Paul Bové on the "Gnosticism" of Harold Bloom:

The dualistic language of inner and outer worlds, of higher and lower, and of world and spirit compels Bloom to this movement out of time. For Kierkegaard, of course, Spirit and World are absurdly combined by virtue of the paradox of the Incarnation. For the post-Cartesian and, we might say, pre-existential Bloom, the inherence of the "two" worlds is an impossibility forbidden by his rhetoric and his own aspiration to sublimity. In The Anxiety of Influence, he insists upon the necessity of dualism to the critic and poet (AI, 33, 34, 38-39, 40,71-72). Dualism is not only the "source" of poetic anxiety, but it is a fiction necessary to Bloom's claims that all poets and critics of strength must be 
Gnostics (AI, 84-85, 130). The rhetoric of dualism and of origins compels the conclusion that poets quest for a way out of time and the world and not merely for some imaginative space not filled by their predecessors. The movement out of the world and time can only be justified if the "world," the "other" is Gnostically devalued and thus seen as inhibiting the creation of poetry itself."

When we turn to the more critically developed forms of this attack in European thought we discover that the Cartesian dualism, especially in the form of Kant's epistemology, is a point of common issue in thinkers who otherwise diverge considerably in their critical views. Typical of these is, for example, that of Theodor Adorno who, in his co-authored Dialektik der Aufklärung, suggests that there is a direct correspondence between the so-called Copernican Revolution in Kant's epistemology and the triumph of ideology in post-Kantian bourgeois culture. In demonstrating that all scientifically certain knowledge is based on the organization of a priori structures of the human mind which constitute the ultimate condition for the possibility of all experience, Kant constructed a paradigm which corresponds to the controlled culture of the late capitalist period. In the culture industry, for example, all information is processed by the media according to exclusive a priori categories approved by the system which determines the form all experience must take. The audience is no more free to experience unprocessed reality than Kant's transcendental subject is free to experience the thing-in-itself. ${ }^{2}$

In Europe such voices could be multiplied almost endlessly, with the implication that the dualism of Descartes and Kant is one of the clearest expressions of the will to power in the Western development, that the pursuit of science and technology did not spring wholly from an altruistic search for impartial truth, but rather from a too often unacknowledged desire to master nature and turn its energy into a standing-reserve ${ }^{3}$ in pursuit of an ever more hedonistically conceived notion of human happiness. The frightening duplicity of this goal was already foreseen at the beginning of the 19th century in Goethe's portrayal of Faust's industrial, technological ambitions. Faust dreams of creating a new land inhabited by free people, but the realization of the dream is subject to unconscious motives repressed and projected into his willing servant Mephisto who, unencumbered by any "prejudices" or traditions, kills Philemon and Baucis in cold blood in the interest of total possession and control. The 20th century has brought with it an ever increasing fear of such duplicity when man, totally isolated from nature, can no longer see the world in the simplicity of its immediacy 
outside the forms imposed by ideological manipulation. And so, contemporary critical theory, in grounding itself philosophically, steps beyond the more limited areas of traditional poetics and literary history and confronts those questions of life and death which traditional philosophy, in its excessive zeal for methodological certainty, relegated to the care of humanists and poets, that is, to those who recalcitrantly refused to submit all experience to mathematical system.

It is in the context of this developing struggle that we begin to understand that the shift in critical perspective involves a prior and more fundamental shift in ontological orientation. It therefore comes as no surprise to find that one of the more persistent critical issues during the course of this century has been that of the relation between art and truth, between aesthetics and epistemology. If indeed it is correct that truth attains its only clear and compelling presentation in the logical proposition or the mathematical formula, then art, along with religion, must be relegated to that no-man's-land of cultural expression often referred to as "mysticism," with the obvious implication that in the serious business of life, namely the mastery of nature, such private concerns are negligible. So overpowering did this notion become that many who dared defend art as a form of genuine knowledge did so in terms of the only discourse available and acceptable, that of the Cartesian dualism. They ended up in the wretched position of defending art as philosophical and moral statement, the triumph of the paraphrase.

This conflict has brought about in our time the formation of a discernible, but often shifting line of battle: on the one side the formalists with their general insistence on a scientific, objective, and structuralist approach to the text, whether literary or philosophical; on the other, a loosely connected group of thinkers generally associated with the development of phenomenology and largely acknowledging Nietzsche and Heidegger as the source of inspiration. Typical of this second group is the more or less violent reaction to the dualistic tendencies of Descartes and Kant, indeed to the whole Platonic tradition. It is among these that the demand for new solutions, not only to literary problems, but to the more pressing questions of modern life, led to the search for a new ontological orientation.

It is particularly in the work of Hans-Georg Gadamer that this confluence of art and philosophy - philosophy as shaped in the development of phenomenology from Husserl to Heidegger - received a problematic but compelling voice. Over this endeavor one could place as motto Gadamer's commentary on Dilthey's assessment of the position 
of Wilhelm Scherer in the development of nineteenth-century literary history and criticism:

In his obituary for Wilhelm Scherer, Dilthey emphasizes that the spirit of the natural sciences guided Scherer's procedure, and he attempts to give the reason why Scherer let himself be so influenced by English empiricism: 'He was a modern man, and the world of our forebears was no longer the home of his spirit and his heart, but his historical object.' Hence Dilthey sees scientific knowledge as involving the dissolution of the connection with life, the establishing a distance from its own history to become an object. ${ }^{4}$

It is precisely this divorce between thought and life, between thought and being, which leads Gadamer to his criticism of aesthetic consciousness, the point of departure for his Wahrheit und Methode of 1960. Gadamer shows in detail how Kant, in his attempt to ground the universality of man's response to beauty, must eliminate all cognitive elements from the aesthetic experience. Both the product of art and its interpretation are rooted in the creative act of genius which has its origin in that sphere of life which is inacessible to natural cognition. In so doing Kant uprooted the human sciences from the fertile soil of their own self-understanding.

It was the end of a tradition, but also the beginning of a new development. It limited the idea of taste to an area in which, as a special principle of judgment, it could claim independent validity - and by so doing, limited the concept of knowledge to the theoretical and practical use of reason. His transcendental purpose was fulfilled by the limited phenomenon of judgment of the beautiful (and sublime) and removed the more general experimental concept of taste and the activity of aesthetic judgment in the area of law and morality from the centre of philosophy. ${ }^{5}$

The most important issue of Kant's subjectivization was for Gadamer the development and eventual impasse of historicism, to which he devotes a long section of part two of Wahrheit und Methode. According to Gadamer, the historicists failed because they were unable to break out of the epistemological dilemma of Neo-Kantianism. They insisted on objectifying the past, and believed its meaning could, by using the method of scientific research, be restored in its original form without any reference to the actual moment of the interpretative event. In this case the truth of the past would be simply the correspondence of what actually happened with its ideal reconstruction in my own mind. In 
this extreme instance the historicist is simply locked into an antequarian stance which, with its value free approach, allows no claim of the past on the being of the researcher. As a historian I am obliged to take up a position outside the living context of both the historical moment and the present moment of my own life. If I take up such a position, I effectively exile myself from all concretion of the real and as a scholar am condemned to live in a world of pure objects which have lost their connection with the life process.

For Gadamer, the breakthrough comes with Heidegger's realization that Being itself is time and that consequently transcendental subjectivity had to be abandoned altogether. On the basis of Husserl's analysis of the life-world Heidegger was able to ground philosophical reflection in a pre-objective realm of irreducible temporality. Understanding is thus "the original form of the realisation of There-being, which is beingin-the world. Before any differentiation of understanding into the different directions of pragmatic or theoretical interest, understanding is There-being's mode of being, in that it is potentiality-for-being and "possibility"." This conception of understanding, on which Gadamer's critical theory is admittedly based, has its roots, then, in Heidegger's own ontological re-orientation. This re-orientation, in turn, is linked to certain controversial aspects of the German tradition, one of which is certainly Nietzsche's attack on the notion of "objective" truth.

The association of Nietzsche and Heidegger with this movement has brought with it considerable complication. The tendency to identify these two thinkers, as well as the entire neo-romantic movement at the beginning of the century, with the destructive political development of fascism seems to support the formalist assertion that existentialism and/ or phenomenology contributed to the spread of irrationality and intellectual obscurantism during this period. In Heidegger's case the bewildering intricacies of inaccessible imagery has given rise to the rather facile and certainly misleading conclusion that the philosopher is quite simply "esoteric;" another word for Wittgenstein's "mystical," and with the similar implication that his later thinking wound up on an irrelevant side-track.

The word "esoteric," as used by the formalists, is meant, of course, to convey an attitude of irrelevance and indifference. But seriously, the word is often used to denote a somewhat muddy stream of unorthodox religious and quasi-philosophical teachings under the various names of Gnostic, Kabbalistic, Hermetic, etc., associated in the popular imagination with the symbologies of the occult: astrology, tarot, al chemy. Such esoteric groups have generally existed on the fringes of 
the Western social and intellectual worlds, with the important exception of the Renaissance, particularly in Germany where many of the leading minds found in such ideas a conceptual vehicle viable enough to challenge the sterile abstractions of a decaying scholasticism. For the German tradition from Romanticism to the present the most significant fruit of that period is the Naturphilosophie of Jacob Boehme who was an older contemporary of Descartes and whose so-called esoteric writings have been influential in all German revolts against the Cartesian tradition. Boehme's work actually has little in common with the typical figures of the occult tradition. He made use of the occult symbols, avidly studied in his hometown of Görlitz at that time, to try to formulate a new ontology which I am here calling, for want of a more adequate term, an ontology of non-duality.*

Heidegger's occasional references to Boehme in the published work and his pointed use of a couplet of Johannes Scheffler, a 17th century poet and disciple of Boehme, in the major treatise, Der Satz vom Grund (1957) are already sufficiently known to presume Heidegger's knowledge of Boehme's work. But more important for our present interest is the less widely known commentary of Heidegger on one of Schelling's last published works, Of Human Freedom (Philosophische Untersuchungen über das Wesen der menschlichen Freiheit) of 1809. Although published in 1971, this commentary on Schelling goes back to a series of seminar lectures presented by Heidegger in the summer semester of 1936 at the University of Freiburg.

It is to the affinity among these three thinkers that I would now like to turn, not as an end in itself, but in order to allow the contours of a developing ontology to emerge, with which we can then return to our discussion of Gadamer's conception of Fusion. In order that we might keep this orientation in mind, I would like to quote two texts of Heidegger's which are typical of his writing on art and poetry and which also have the reputation of being esoterically difficult.

Truth establishes itself in the work. Truth is present only as the conflict between lighting and concealing in the opposition of world and earth...The conflict is not a rift (Riss) as a mere cleft

* It is with some reluctance that I use a term familiar primarily to students of Buddhist thought and, if at all, is at present visible only on the far horizon of critical theory. I have chosen to retain it in the present instance because first, we really have no functional substitute and second, there is a growing realization that the thought of both Boehme and Heidegger is going to be of major importance in the continuing dialogue between East and West. 
is ripped open; rather, it is the intimacy with which opponents belong to each other. This rift carries the opponents into the source of their unity by virtue of their common ground. It is a basic design, an outline sketch, that draws the basic features of the rise of the lighting of beings. This rift does not let the opponents break apart; it brings the opposition of measure and boundary in to their common outline. ${ }^{7}$

The speaking of the first two stanzas speaks by bidding things to come to world, and world to things. The two modes of bidding are different but not separated. But neither are they merely coupled together. For world and things do not subsists alongside one another. They penetrate each other. Thus the two traverse a middle. In it, they are at one. Thus at one they are intimate. The middle of the two is intimacy - in Latin, inter. The corresponding German word is unter, the English inter. The intimacy of word and thing is not a fusion. Intimacy obtains only where the intimate - world and thing - divides itself cleanly and remains separated. In the midst of the two, in the between of world and thing, in their inter, division prevails: a dif-ference. ${ }^{8}$

The first passage comes from The Origin of the Work of Art (Der Ursprung des Kunstwerkes), the published version of which is based on a lecture which Heidegger first gave in 1935. The second passage comes from Language (Die Sprache) which Heidegger gave twice as a lecture in the years 1950 and 1951 and is primarily devoted to a discussion of Trakl's poem "Winterabend." I have quoted both of these works, not out of a penchant for redundancy, but rather to demonstrate clearly how central and persistent are the language and imagery used by Heidegger from the 1930's to the 1960's. In this context we must also not forget that Heidegger gave his first Hölderlin interpretations in 1935 and that the seminar on Schelling, as mentioned before, was held in 1936.

The language Heidegger uses here is not what we would call philosophical in the traditional sense. The imagery of rift and design, the opposition of light and dark are more typical of poetic imagery. (He does indeed avoid the reduction of philosophical language down to the efficiency of contemporary analysis.) In driving philosophical reflection back to the realm of pre-objective experience, Heidegger discovered, for example, the highly metaphorical language of Heraclitus. In a seminar on this pre-Socratic thinker given by Heidegger and Fink in the winter semester $1966 / 67$, there is a great deal of meditation on the imagery of the lightning flash in the darkness of the night sky. ${ }^{9}$ Heidegger discovered a similar unity of thought and poetry in the works of Jacob Boehme whose ontology is expressed almost entirely in the 
language of the Kabbalah. That is what we now want to look at more closely.

We can best venture into the region of the problem by briefly summarizing the principal elements of Boehme's ontology. The difficulty lies primarily in translating the metaphors into some commonly acceptable terminology, and students of critical theory have been helped in this by such works as that of Gerhard Scholem, ${ }^{10}$ the close friend of Walter Benjamin, and Harold Bloom, whose Kabbalah and Criticism introduces the esoteric material in the context of his own critical theory. ${ }^{11}$ Boehme's thought is most easily approached from a structural point of view. He himself refers to its most general pattern as "the Trinity on the cross" (Die Drey-Zahl auf dem Kreutz), since the dialectic of the numbers two, three, four, and seven plays a major role in the symbolism. Let us momentarily follow the unfolding of this dialectic.

At a certain moment in the timelessness of unmanifest eternity, Being yearns to manifest itself, a yearning which is ultimately based on the motion of love and yet involves a moment of anguish and darkness. The initial moment of manifestation, the first movement of the free, divine spirit, Boehme calls the ungrounded will. Now no manifestation can occur until this ungrounded will is grounded; and it can be grounded only by positing that which is not itself. But since there exists nothing outside the divine spirit, it must clear a space within itself, which is in itself but is not itself. This space is what Boehme calls nature, the dark world of the divine ground, similar to an unreflecting mirror into whose darkness the spirit sacrifices its freedom in its anguished yearning to reveal itself.

Thus, the first will (which is called Father, and is itself freedom) desires Nature, and Nature with great longing desires freedom, that it may be released from the torment of anguish ... The terror of its Nature is a kindler of fire. For when the dark anguish, as the very fervent, stern being, receives freedom in itself, it is transformed in the terror, in freedom, into a flash, and the flash embraces freedom or gentleness. ${ }^{12}$

Thus the absolute indifference of pre-manifest Being gives birth out of itself to two contrary motions: first, the freedom of the creating light; second, the negation of Being in the form of fear and darkness. These two manifestations are co-equal and, in the analogical terms of temporal succession, absolutely co-eternal.

But Boehme is, of course, no Manichaean dualist. The presupposition 
of unmanifest reality itself Boehme calls the Ungrund, or equally often, Nothingness (Nichts). It is a dimension of reality of which absolutely nothing can be predicated, neither that it is, nor that it is not. It is, in its absolute indifference, both the plenitude of reality and the emptiness of nothingness. Those who are familiar with the symbols of the Kabbalah will easily recognize a variation of the En Soph. ${ }^{13}$ The importance of this conception for us is that it grounds the dialectic of identity and difference which underlies Boehme's entire system.

This dialectical process, carried out by the traditional seven spirits of nature, is one of open conflict. The desire to manifest demands the creation of real darkness without which the light of manifestation cannot be seen. But the severe contraction, by which the dark world is formed in the free spirit, arouses in it the raging desire to escape this prisonhouse of darkness. Of course there is no escape. The paradox is unresolvable. The light which desires to be manifest must desire equally strongly both the creation and the endurance of the darkness which makes manifestation possible. Thus the life process consists in continually overcoming a darkness which can never be completely overcome.

The danger inherent in all of Boehme's attempts to describe this dialectic is the strong temptation to reify these two worlds, to assume, somewhat in the Cartesian fashion, that they are really and actually separate worlds, and that we must now find some way of putting them back together again in order to resolve the conflict. But, of course, such is not the case. The moment in which the darkness is born out of the light is also the moment in which the light is born out of the darkness. They are different, yet they are identical. This moment is symbolized throughout Boehme's works by the lightning flash. Its action both differentiates the light from the dark by showing the absolute difference between them; and simultaneously unifies them by showing their primordial identity. This moment of the lightning flash represents in Boehme's system of imagery the birth of the seventh divine spirit of nature which Boehme calls fire and is the center, the between, the middle through which and in which reality attains its ineffable concreteness. Neither language nor concept can capture it, and yet it is the presupposition of all language and concept.

We know from Robert Brown ${ }^{14}$ who, in his book on the later philosophy of Schelling, summarizes the few facts available on Schelling's reception of Boehme, that Schelling, along with Hegel, was introduced to the thought of Boehme in the Schlegel circle in the year 1799, that 
he was able to procure Boehme's work in 1804, and that Franz von Baader, a colleague of Schelling's at Munich and an ardent disciple of Boehme, further influenced Schelling's thinking in these first years of the new century. Anyone, however, who reads Schelling's Treatise on the Nature of Human Freedom of 1809 needs no further proof of how significant Boehme's impact was on Schelling's thought during these years, even though the word Kabbalah appears only once and Boehme's name not at all.

As is well known, the central concern of Schelling's Treatise is to demonstrate that human freedom, and consequently human evil, has its roots in the very act by which God created a free and finite being. Therefore evil must, somehow, be in God, since God comprehends all Being. But at the same time evil cannot be caused by God, since he is the source of all love. The solution to the apparent contradiction becomes possible for Schelling on the basis of a new ontology, which is fully formulated for the first time in this work. For this purpose he, like Boehme before him, distinguishes two aspects of the divine life: ground (Grund) and existence (Existenz), corresponding precisely to Boehme's distinction between the dark world of the divine ground and the light world of divine freedom. That there is no temporal succession involved in their simultaneous emanation is somewhat facetiously demonstrated by recalling the age-old question: which came first, the chicken or the egg? But this question points to one of the most serious implications of this developing ontology: the search for temporal origin is an illusory path, at most leading, if one is lucky, into the circle of dialectical mediation. To say that each polar element absolutely presupposes the other leads to the heart of Schelling's ontology:

In the circle, out of which every thing comes to be, it is no contradiction to say that that which gives birth to the One comes itself to birth through the One. Here there is no first and no last, because everything is presupposed by everything else. No one thing is the other, yet its existence depends on the other. God has in himself an eternal ground of his existence which, insofar as he exists, precedes him; but likewise God is the presupposition of the ground, since the ground, as such, could not exist if God did not exist in actuality. ${ }^{15}$

Of course, Schelling's ontology is still completely embedded in a philosophical theology, and, according to Brown, the development of his later positive theology involved a severe modification, if not outright rejection of Boehme's postulate of the Ungrund. The point is still dis- 
puted in the Schelling literature and need not concern us here.

Of greater interest for our discussion is the fact that Heidegger, when choosing a work of Schelling for the seminar of 1936, chose the Treatise on Human Freedom, which represents the moment of Boehme's greatest impact on Schelling's developing ontology. And indeed Heidegger, somewhat inadvertently, gives the reasons for his choice within the commentary itself. At the center of the discussion on ontology he says:

At this point the utter boldness of Schelling's thought comes into play. But it is no empty-headed game of a high-flying loner. It is simply the consummation of an intellectual attitude which begins in Meister Eckhart and attains in Jacob Boehme a unique exposition. But as soon as we recall this historical context the usual slogans begin to appear; there is talk of "mystic" and "theosophy"...Schelling is no mystic in the sense usually meant in this case, a rattle-brain who likes to stagger around in the dark and amuse himself with mystifications. ${ }^{16}$

The high point of these lectures is the discussion of Schelling's ontology, revolving around the duality of ground and existence. He likens the ground to gravity with its characteristics of contraction and shriveling, hence withdrawal and fleeing. Existence, as its name implies, designates the opposite moment in the dialectic of being, the expansive, the evolutionary. What is obscured steps out of the confines of darkness into the light. For the light is always the illumination of that which is concealed, dark, and irrationally entangled. But the real point at issue here, as it was in Boehme and Schelling, is the precise determination of the kind of relation which governs this duality. There is obviously a genuine separation, since the presupposition of all three thinkers is that real illumination demands real darkness, not an idealist abstraction. Concrete individuality is possible only if the state of perfect unity is truly sacrificed in a moment of anguish. But the very notion of perfect unity is, in turn, an abstraction which has no genuine actuality until it is grounded in darkness. Each of the two principles, then, is actually realized only in and through the other. Both the reification of the difference as well as that of the unity brings with it a fateful distortion of the nature of reality. Heidegger sums up Schelling's exposition in the following passage of the lectures:

When God first catches sight of himself in the hidden self-searching of yearning, there occurs the first existing. But this is not something that follows yearning in temporal succession. Rather it belongs to it co-eternally, as measured in the eternity of be- 
coming. Just as the ground is ground only in respect to existence, so the act of stepping out of itself toward itself is simply a stepping out of the ground. But we must not say that existence rejects the ground. On the contrary, as existing, the primal Being places itself precisely back into its ground. As existent, it has assumed the ground eternally, and thereby affirmed yearning as an eternal moment. Thus it is and remains a continual self-consuming that never consumes itself, but rather flares up into an inextinguishable flame, in order to maintain, in its own appropriate darkness, the light which has been kindled in it. ${ }^{17}$

The disclosure of Being in the darkness of finite articulation is not to be conceived as the instrumenting of a pre-existing, but unmanifest idea. The idea which is articulated has no concrete reality before its articulation, just as the instrument of articulation has no appropriate formation before the inchoate idea submits itself to instrumentation. The ontological principle on which this conception is based received consummate expression, appropriately enough, in Heidegger's discussion of man's confrontation with the question of technology in The Turning (Die Kehre), first given as a lecture in 1949. One notes the near Boehmean language:

To "flash" (blitzen) in terms both of its derivation and of what it designates, is "to glance" (blicken). In the flashing glance and as that glance, the essence, the coming to presence, of Being enters into its own emitting of light. Moving through the element of its own shining, the flashing glance retrieves that which it catches sight of and brings it back into the brightness of its own looking. And yet, that glancing, in it giving of light, simultaneously keeps safe the concealed darkness of its origin as the unlighted. The inturning (Einkehr) that is the lightning flash of the truth of Being is the entering, flashing glance - insight. ${ }^{18}$

With this background in view, we can now briefly return to those passages quoted earlier from Heidegger's essays on art and poetry. By now it is clear, I believe, that Heidegger's vocabulary is not nearly so idiosyncratic as some critics have suggested. Terms such as "flash," "center," and "rift" have a very specific meaning seen in the light of the appropriate context. And we also recognize that these are not essays on aesthetics in any narrow sense. Nothing could be more deceiving than to call the concept of being here an "aesthetic ontology" as Frank Lentricchia, for example, has suggested. ${ }^{19}$ Among the several ways in which truth can be primordially disclosed, art happens to be one of the most important ones, and this alone accounts for its central 
position in Heidegger's later thinking. On the other hand, mathematics and natural science, at least in the post-Cartesian form of method, are not based on such a primordial disclosure. This should not be construed as a prejudice against science, as has too often been the case. It is simply a fact, springing quite logically from Heidegger's basic ontological position and in no way questions the value of science in its own sphere of legitimacy. Heidegger insists, however, that the primordial manifestation of truth, wherever it occurs, must be the result of the pre-objective conflict between Lichtung (clearing) and Verbergung (concealment). This non-dual relationship between light and dark is the decisive context for the comprehension of any of the primordial modes of human activity, including, as Heidegger expressly tells us, art, religious sacrifice, and the formation of human community.

Art can be a place where truth primordially happens because the unresolvable paradox, in the form of the conflict of desire and flight, becomes visible in the mediation of world and earth by the thing. The nothingness of undisclosed Being can be revealed in its fullness only by allowing the darkness of a particularized thing to be illumined and grounded as the particular thing it truly is. The totality of Being withdraws into the darkness, denies its fullness in the emptiness of nothingness, only to emerge from the center of mediation back into the light of finite articulation. On the dark matter of Van Gogh's shoes falls the light of Being and illumines them in the particularity of their limitation; at the same time the illumined brilliance of the shoes discloses the horizon of a world in its articulated totality, just as the dark wick of a candle, to use one of Boehme's favorite metaphors, bursts like a flash into flame which articulates the darkness of the surrounding dwelling. Every work of art is such a flashing glance of insight into that which truly is.

During the gradual development of this ontological position, Heidegger clarified what was from the beginning the phenomenological enterprise: the contemplation of beings without the imposition of any artificial, teleological constructs. But within this new context it is apparent that to let a thing appear as it is, is not only a cognitive, but a moral and aesthetic event as well. The word Gelassenheit with which Heidegger designates this attitude of non-attachment, allowing a thing to appear as that which it really is, has deep roots in the German mystical tradition from Meister Eckhart on. By this act of freedom in which we refuse to dictate to a thing how it can appear in order to satisfy the whim of egocentric desire, the thing becomes free to reveal, from its own unique perspective, the totality of the disclosed world. Even 
man himself, who in this respect is a thing among things, breaks out of the distortions of inauthenticity, imposed by both vision and will, and realizes himself as a vehicle of authentic disclosure. In this moment of ecstasy, standing out into the openness of Being, the illumination of the mind coincides with the rapture of the will:

Knowing that remains a willing, and willing that remains a knowing, is the existing human being's entrance into and compliance with the unconcealedness of Being. The resolutness intended in Being and Time is not the deliberate action of a subject, but the opening up of human being, out of its captivity in that which is, to the openness of Being. ${ }^{20}$

At the same time this standing out into the disclosure of Being is accompanied by a radiant shining which we call beauty:

The more simply and authentically the shoes are engrossed in their nature, the more plainly and purely the fountain is engrossed in its nature - the more directly and engagingly do all beings attain to a greater degree of being along with them. That is how selfconcealing being is illuminated. Light of this kind joins its shining to and into the work. This shining, joined in the work, is the beautiful. Beauty is one way in which truth occurs as unconcealedness. ${ }^{21}$

There is no authentic truth which is not at the same time a moment of joy and beauty. To separate them is to fall inevitably into inauthentic disclosure where the intellect is blinded, the will becomes barren, and the radiance of beauty flees back into the darkness of concealment.

This ontology, on the basis of which Heidegger comes to see art as one of the primary occasions of the disclosure of truth is also the basis for Gadamer's solution of the problems of aesthetic consciousness and historicism. Indeed it has been he who most faithfully extends to the realm of philosophical hermeneutics the ontological position of Heidegger's later period. In the subjectivisation of experience, ultimately locked into the abstraction of the transcendental ego, corresponds an equally abstract objectification of experience congealing in the value-free attitude of scientific research. The analysis of the problem by Gadamer in Wahrheit und Methode has been the subject of a good deal of controversy, largely, it seems to me, because there has been a general failure to see its connection with the ontological position on which it is based. In no sense can it be said that he is opposing hermeneutical experience to methodological knowledge. Nor is he saying 
that reflective understanding and the consequent methodological alienation of the object has no place in the hermeneutic sciences. He is however clearly saying that reflective understanding must, in order to maintain its critical insight, be continuously fed by a pre-scientific, pre-philosophical experience in which past and present are authentically mediated. ${ }^{22}$ This is precisely the import of Gadamer's conception of the fusion of horizons. The past became an abstraction when conceived as lying outside and independent of the interpreter's understanding. This is likewise true for a present which, because of extreme alienation, is thought of as detached from all tradition. Genuine understanding, on the other hand, can only grow out of a tension or conflict between my present horizon and that of the past event I am seeking to understand. The fusion of these two horizons refers to that moment when the concern for my own being becomes the center in which the past and present are mediated in the act of understanding. The center in which this fusion takes place is the moment of the flash of insight familiar to us now from Boehme and Heidegger. The insight which occurs here, however, is not the product of reflection. In fact reflection is impossible until the flash of insight has achieved differentiation in structure and brought forth the language in which it can be expressed, both of which occur within the limitations of the immediate historical situation. The Totality of Being is, in itself, ineffable, but can, of course, show itself in phenomenological disclosure. But since it is as such ineffable it can show itself only by indirection, can only show itself by not showing itself. To use the language of Boehme, the Ungrund can show itself only by positing what is not itself, the limited, finite thing and allow this finitude to reflect the totality of the ineffable Ungrund. The accusation of relativism here quite misses the point, as Gadamer has tried to explain. What shows itself in every historical manifestation is, of course, the thing-in-itself, even though this occurs only by indirection and from a limited perspective. Genuine relativism arises only if we assume with the Neo-Kantians that we and the phenomenon are in a box, outside of which lies the completely unknowable noumenon, all speculation on which would then be purely subjective and therefore purely relative.

Like Heidegger before him, Gadamer turns to the work of art in order to clarify this ontological process. It is particularly visible in the discussion of drama, where the moment of trans-subjective play is transformed into structure, for which the presence of an audience is a distinctive feature. The play having, in the form of book or manuscript; handed down from the past, only diminished being, has its 
full being only in the moment of representation where the historical horizon of the dramatic material is fused with the present horizon of the audience through the mediation of the actors. This mediation is total. At the moment of presentation the world of the play is hermetically closed. "In so much as it is a structure, it has, so to speak, found its measure in itself, and measures itself by nothing outside it." 23 Only through this aesthetic containment is it possible for the play to present a world in which the inessential trivia, characteristic of everyday experience, has been eliminated in the interest of high-lighting the essence. But this certainly does not mean that there is no referential connection between the world on the stage and the world in which I am concerned about my own being. In discussing tragedy, for example, Gadamer says:

Being overcome by distress and horror involves a painful division. There is a disjunction with what is happening, a refusal to accept, that rebels against the agonizing events. But it is precisely the effect of the tragic catastrophe that the disjunction with what exists is removed...We are freed not only from the spell in which the painful and horrifying nature of the tragic destiny had held us, but at the same time we are freed from everything that divides us from what is. ${ }^{24}$

The drama, as we inherit it from the past, is an ineffable totality. The being of which depends totally on representation. To understand the drama, I cannot abandon the present horizon of my own existence and seek to restore that moment of the past out of which the drama was born, as if the object of consciousness could be disclosed in itself in some privileged moment outside of time and outside all mediation. Within the circle of interpretive understanding there is no such moment of origin. In fact, from the point of view of what we have called a nondual ontology, the quest for temporal origin is both illusory and reprehensible. On the one hand illusory, because it assumes that the darkness involved in the disclosure of being is only accidental and can be overcome by reason's movement out of time, as if we were capable of stepping out of our finite limitations. On the other hand reprehensible, because the desire to abolish the darkness is too often the unconscious expression of the dogmatic insistence on total possession and control. It is in the clarification of this dangerous blindness that Richard Palmer sees the vital necessity of this new critical awareness: 
The "turn" in Heidegger's thought suggests a principle and an issue of highest importance for a post-modern interpretive awareness; for it attacks the conception of man as the king and center of the world of interpretations, the inventor and user of language, the holder of tremendous technological power. ${ }^{25}$

\section{NOTES}

1. Paul Bove, Destructive Poetics (New York: Columbia University Press, 1980) p. 12 .

2. See particularly Max Horkheimer and Theodor W. Adorno, "Kulturindustrie: Aufklärung als Massenbetrug" in Dialektik der Aufklärung, Gesammelte Schriften Vol. 3 (Frankfurt am Main: Suhrkamp Verlag, 1981).

3. This is William Lovitt's translation of Heidegger's Bestand which, along with Gestell, plays such an important conceptual role in Heidegger's discussion of technology. See Martin Heidegger, The Question Concerning Technology and Other Essays, trans. William Lovitt (New York: Garland Publishing Co. Inc., 1977) p. 17.

4. Hans-Georg Gadamer, Truth and Method (New York: Seaburry Press, 1975) p. 8 (No translator is given).

5. Ibid., p. 38.

6. Ibid., p. 230.

7. Martin Heidegger, 'The Origin of the Work of Art' in Poetry, Language, Thought, trans. Albert Hofstadter (New York: Harper and Row, 1971) p. 6263.

8. Ibid., p. 202.

9. Martin Heidegger and Eugen Fink, Heraclitus Seminar 1966/67, trans. Charles H. Seibert (The University of Alabama Press, 1979).

10. See particularly Gershom Scholem, Kabbalah (Jerusalem: Keter Publishing House, Ltd, 1974).

11. Harold Bloom, Kabbalah and Criticism (New York: The Seaburry Press, 1975).

12. Jacob Boehme Six Theosophic Points, trans. John Rolleston Earle (Ann Arbor: The University of Michigan Press, 1958) p. 17-18.

13. For one of the more readable introductions to the Kabbalistic tradition in English see Leo Schaya, The Universal Meaning of the Kabbalah, trans. Nancy Pearson (Baltimore: Penguin Books Inc., 1973).

14. Robert F. Brown, The Later Philosophy of Schelling: The Influence of Boehme on the Works of 1809-1815 (Lewisburg: Buckness University Press, 1977).

15. Friedrich Wilhelm Joseph Schelling, "Philosophische Untersuchungen über das Wesen der menschlichen Freiheit und die damit zusammenhängenden Gegenstände" in Schellings Werke, Vol. IV, ed. Manfred Schröter, Facsimile of the 1927 edition (Munich, 1958) p. 250. (Translation by the author).

16. Martin Heidegger, Schelling Abhandlung über das Wesen der menschlichen Freiheit (1809), ed. Hildegard Feick (Tübingen: Max Niemeyer Verlag, 1971) p. 140-149. (Translation by the author).

17. Ibid., p. 152. 
18. Op.cit., Heidegger, trans. William Lovitt, p. 45.

19. Frank Lentricchia, After the New Criticism (The University of Chicago Press, 1980) p. 89.

20. Op.cit., Heidegger, Poetry, Language, Thought, p. 67.

21. Ibid., p. 56 (Underlining is Heidegger's).

22. Jan Garrett has worked out this difference very neatly by distinguishing between what he calls tacit and non-tacit fusion. See Jan Edward Garrett, "HansGeorg Gadamer on "Fusion of Horizons" Man and World 11 (1978) p. 397.

23. Op.cit., Truth and Method, p. 101.

24. Ibid., p. 116.

25. Richard E. Palmer, "The Postmodernity of Heidegger, "Boundary 2, IV (1976) p. 428 . 